GRASAS Y ACEITES 66 (4)

October-December 2015, e107

ISSN-L: 0017-3495

doi: http://dx.doi.org/10.3989/gya.0239151

\title{
Optimization and evaluation of foxtail millet (Setaria italica) bran oil by supercritical carbon dioxide extraction
}

\author{
M. Pang ${ }^{\mathrm{a}, \mathrm{b}, \varpi}$, S.J. He ${ }^{\mathrm{a}, \mathrm{b}}$, L.L. Cao ${ }^{\mathrm{a}, \mathrm{b}}$ and S.T. Jiang ${ }^{\mathrm{a}, \mathrm{b}}$ \\ ${ }^{a}$ School of Biotechnology and Food Engineering, Hefei University of Technology, Hefei, 230009, P. R. China \\ ${ }^{b}$ Key Laboratory for Agricultural Products Processing of Anhui Province, Hefei, 230009, P. R. China \\ ${ }^{\square}$ Corresponding author: pangmin@hfut.edu.cn
}

Submitted: 04 February 2015; Accepted: 23 June 2015

SUMMARY: A Box-Behnken central composite design combined with the response surface methodology (RSM) was used to optimize the parameters of a supercritical fluid extraction (SFE) of foxtail millet bran oil (FMBO). Results showed that a maximum oil yield of $7.97 \%$ was achieved under the optimal conditions with an extracting pressure of $30.03 \mathrm{MPa}$, extracting temperature of $47.93^{\circ} \mathrm{C}$; and an extraction time of $2.3 \mathrm{~h}$. The quality of the oil obtained from SFE and solvent extraction (SE) was evaluated by proximate analysis to include physicochemical properties, fatty acids and sterol compounds. The FBMO obtained from SFE showed a much lower phospholipid $(0.188 \mathrm{mg} / \mathrm{g})$ content and a preferable color compared to the oil from SE, while it contained a higher content of total sterols, $1.55 \%$. The thermal gravimetric analysis results showed one major regime of weight loss over a temperature range of $300-500{ }^{\circ} \mathrm{C}$. The results show that FBMO obtained by SFE can be a promising nutritional source for food fortification and is understood to have more potentially healthy biological properties.

KEYWORDS: Fatty acids; Foxtail millet bran oil; Physicochemical properties; Phytosterols; Reponses surface methodology; Supercritical carbon dioxide extraction

RESUMEN: Optimización y evaluación de aceite de salvado de mijo (Setaria italica) mediante extracción supercrítica con dióxido de carbono. Un diseño Box-Behnken combinado con la metodología de superficie de respuesta (RSM) se usó para optimizar los parámetros de extracción mediante fluido supercrítico (SFE) de aceite de salvado de mijo (FMBO). Los resultados mostraron que un rendimiento máximo de extracción de aceite del 7,97\% se logró en las condiciones óptimas correspondientes a una presión de $30.03 \mathrm{MPa}$, una temperatura $47.93{ }^{\circ} \mathrm{C}$ y un tiempo $2,3 \mathrm{H}$. Además, se evaluó la calidad del aceite obtenido por SFE y mediante extracción con disolvente (SE) a partir de un análisis proximal que incluye propiedades fisicoquímicas, ácidos grasos y esteroles. El aceite de FBMO obtenido mediante SFE mostró un contenido mucho menor de fosfolípidos $(0.188 \mathrm{mg} / \mathrm{g})$ y un color mas aceptable que el aceite de la SE, mientras que contenía un mayor contenido de esteroles totales: 1,55\%. El resultado del análisis térmico gravimétrico mostró un régimen importante de pérdida de peso durante un intervalo de temperatura de $300-500^{\circ} \mathrm{C}$. Los resultados muestran que FBMO obtenido por SFE puede ser una fuente nutricional prometedora para la fortificación de alimentos y se supone potencialmente que tiene mejores propiedades biológicas saludables.

PALABRAS CLAVE: Aceite de salvado de mijo; Ácidos grasos: Extracción supercrítica con dióxido de carbono; Fitoesteroles; Metodología de superficie de respuesta; Propiedades fisicoquímicas

Citation/Cómo citar este artículo: Pang M, He SJ, Cao LL, Jiang ST. 2015. Optimization and evaluation of foxtail millet (Setaria italica) bran oil by supercritical carbon dioxide extraction. Grasas Aceites 66 (4): e107. doi: http://dx.doi. org/10.3989/gya. 0239151

Copyright: (02015 CSIC. This is an open-access article distributed under the terms of the Creative Commons Attribution-Non Commercial (by-nc) Spain 3.0 Licence. 


\section{INTRODUCTION}

Foxtail millet (Setaria italica) is one of the most important cereal crops in semi-arid areas all over the world (Zohary et al., 2012). In China, foxtail millet is planted as one of the major grain sources. Foxtail millet bran, which consists of an anatomical pericarp layer, an aleurone layer and cereal germ, makes up about $8 \%-10 \%$ of millet quality. As a by-product of the millet processing from foxtail millet seed, foxtail millet bran has been extensively used as animal feed in China in the preceding years. Recently, several studies regarding foxtail millet have been reported. The potential effects of antioxidant activity estimations for foxtail millet insoluble fibers were confirmed by using different in vitro tests (Bangoura et al., 2013). The protein, total carbohydrates and crude fat contents of foxtail millet were rapidly and accurately investigated by near infrared spectroscopy (Chen et al., 2013). The purification and characterization of foxtail milletderived peptides with antioxidant and antimicrobial activities were investigated (Amadou et al., 2013). With respect to foxtail millet bran, there are still few reports in spite of the fact that the oil from foxtail millet bran has proved to be rich in polyunsaturated fatty acids (PUFA), especially linoleic acid and several lipid bioactive compounds (Liang et al., 2010; Pang M, 2014).

Because it is rich in PUFA and bioactive constituents, the oil from foxtail millet bran is supposed to have potentially healthy biological properties similar to other edible oils such as olive oil, tea seed oil and rice bran oil, which are rich in unsaturated fatty acids and special antioxidants which are well established as having functional effects against several degenerative pathologies, including cardiovascular diseases, hepatic injury and cancer (Chen and Cheng, 2006; Martinez-Gonzalez and Estruch, 2004; Panagiotakos et al., 2006). The mechanism seems to indicate that the antioxidants and phytochemicals in these edible oils are used as oxygen radical scavengers due to their ability to neutralize the actions of free radicals.

Over the past decades, supercritical fluid extraction (SFE) technology has made a great deal of progress in oil extraction from plant materials (Kim et al., 1999; Shao et al., 2008; Zacchi et al., 2006). With low extraction temperatures and high extraction efficiency, supercritical fluid extraction has also become a widely used type of extraction separation technology in the oil industrial field (Chen et al., 2008; Ge et al., 2002). When oils are extracted using SFE, there is no risk of solvent contamination, thermal ability, or chemical deformation which may often occur in solvent extraction (SE) and the following refining process.

In our previous study, we observed that foxtail millet bran oil (FMBO) is capable of attenuating ethanol-induced hepatic injury in mice (Pang M, 2014). However, the relative research on FMBO is still limited especially concerning the processing of the oil extract from foxtail millet bran. In the present study, the SFE of oil from foxtail millet bran was examined by adopting a three-variable, three-level Box-Behnken design to determine, via response surface methodology, the optimum specifications for extraction pressure, extraction temperature, and time by supercritical $\mathrm{CO}_{2}$. Not only did we establish an economical, convenient and no risk of solvent contamination extraction process for foxtail millet (Setaria italica) bran, but also we evaluated the physicochemical properties, fatty acid compositions and sterols of FMBO obtained by SFE and SE. This report was proposed to provide the theoretical basis for the development and utilization of foxtail millet bran oil.

\section{MATERIALS AND METHODS}

\subsection{Materials and Reagents}

Foxtail millet bran donated from an oil plant in Baishui County (Shaanxi, China) was carefully selected and sieved to remove contaminates. Carbon dioxide (purity $99.9 \%$ ) was purchased from Henglong Gas Corp. (Hefei, China). The methanol used for fatty acid analysis and the hexane used for GC-MS analysis were of HPLC grade purchased from Guoyao Chemical Reagent Co., Ltd. (Chengdu, China). All other reagents were of analytical grade.

\subsection{Analysis of Components of Raw Material}

Moisture, ash, protein, crude fiber and lipid contents were determined according to the protocols established by the Association of Official Analytical Chemists (AOAC). Moisture was 7.39\% which was determined gravimetrically after drying the sample overnight at $105^{\circ} \mathrm{C}$. Total protein content was about $12.2 \%$ when it was established by the Kjeldahl method. Ash was quantified after incinerating the sample overnight at $550{ }^{\circ} \mathrm{C}$ and the value was about $7.5 \%$. The crude fiber content was about $52.3 \%$. The lipid content was about $9.12 \%$ which was expressed as the ratio of lipids extracted by ethyl ether from the original bran.

\subsection{Supercritical Fluid Extraction (SFE) of Oil}

Foxtail millet bran oil was extracted using an HA121-50-01C device (Hua'an Supercritical Fluid Extraction corp., Nantong, China), described in detail by Wei et al., 2009, using carbon dioxide as solvent. Foxtail millet bran samples $(150 \mathrm{~g})$, with the chosen particle size and water content, were loaded into the extraction vessel. Carbon dioxide from a cylinder was passed through a chiller kept 
at $2{ }^{\circ} \mathrm{C}$ and pumped into the extractor by a high pressure pump. The pressure and temperature were controlled to an accuracy of $\pm 0.5 \mathrm{MPa}$ and $\pm 0.5^{\circ} \mathrm{C}$, respectively. The flow rate of $\mathrm{CO}_{2}$ was controlled at $20 \mathrm{~kg} / \mathrm{h}$ for all experiments. After each extraction, the oil was collected in the first separator while water and volatile components were recovered in the second one. The amount of extracted oil was determined gravimetrically after collection and the oil yield percentage was calculated according to the following equation:

extraction rate $(\mathrm{ER})(\%)=\frac{\text { Amount of extracts oil }(\mathrm{g}) \times 100}{\text { Amount of initial bran powder }(\mathrm{g})}$

\subsection{Experimental Design for RSM of SFE}

RSM with three variables and three levels was applied to optimize the extraction rate of millet bran oil. The separating pressure $\left(\mathrm{X}_{1}\right)$, extraction temperature $\left(\mathrm{X}_{2}\right)$ and extraction time $\left(\mathrm{X}_{3}\right)$ were independent variables studied to optimize the RE. The uncoded and coded values of the variables are given in Table 1.The levels of the parameters were based on preliminary experimental results. All experiments were carried out in randomized order. The quadratic polynomial regression model was used to express the $\mathrm{Y}$ variable $(\mathrm{ER}=$ the extract rate of millet bran oil) as a function of the independent variables as follows:

$$
\mathrm{Y}=\beta_{0}+\sum_{\mathrm{i}=1}^{3} \beta_{i} X_{i}+\sum_{i=1}^{3} \beta_{i i} X_{i}^{2}+\sum_{i=1}^{2} \sum_{i=i+1}^{3} \beta_{i j} X_{i} X_{j}
$$

$\beta_{0}, \beta_{i}, \beta_{i i}$, and $\beta_{\mathrm{ij}}$ are constant coefficients of intercept, linear, quadratic and interaction terms, respectively. The data collected from the extraction tests were analyzed using a response surface analysis procedure (Design-Expert 8.0Trial, State-Ease, Inc., Minneapolis MN, USA).

\subsection{Soxhlet extraction procedure}

A conventional method of Soxhlet extraction (SE) was performed in a Soxhlet apparatus to compare the extraction performances with SFE. Foxtail millet bran samples $(5 \mathrm{~g})$ were extracted using petroleum ether $(\mathrm{v} / \mathrm{w}=10: 1)$ as the solvent at room temperature

TABLE 1. Uncoded and coded levels of independent variables used in the RSM design

\begin{tabular}{lccc}
\hline $\begin{array}{l}\text { Coded } \\
\text { variables levels }\end{array}$ & $\begin{array}{c}\text { Extracting pressure } \\
\left(\mathbf{X}_{\mathbf{1}}, \mathbf{M P a}\right)\end{array}$ & $\begin{array}{c}\text { Temperature } \\
\left(\mathbf{X}_{\mathbf{2}},{ }^{\circ} \mathbf{C}\right)\end{array}$ & $\begin{array}{c}\text { Time } \\
\left(\mathbf{X}_{\mathbf{3}}, \mathbf{h}\right)\end{array}$ \\
\hline-1 & 25 & 40 & 1.5 \\
0 & 30 & 45 & 2 \\
+1 & 35 & 50 & 2.5 \\
\hline
\end{tabular}

for $24 \mathrm{~h}$, evaporated at $60{ }^{\circ} \mathrm{C}$ to remove the solvent and then the oil was obtained.

\subsection{Assay for physicochemical characterization of FMBO}

\subsubsection{Physicochemical property assays for FMBO}

Important physicochemical properties of the crude FMBO, concerning specific gravity, refractive index, saponification value, acid value, peroxide value, and phospholipid content were characterized according to the AOCS methods (Firestone, 1998). The color of the oils was determined by the lovibond tintometer (Shanghai Technologies, China). Three replicates were carried out for each analysis.

\subsubsection{Fatty acid composition of FMBO}

The fatty acid composition of FMBO was analyzed according to the AOCS method. A Shimada GC-MS-QP2010 (Shimadzu Co., Kyoto, Japan) equipped with a capillary column (DB-wax, $30.0 \mathrm{~m} \times 0.25 \mathrm{~mm}, 0.25 \mu \mathrm{m}$ film thickness, Agilent Technologies Co., Ltd.) was used. The GC parameters were: the carrier gas, high purity helium; injector temperature, $250{ }^{\circ} \mathrm{C}$; detector temperature, $320^{\circ} \mathrm{C}$; split ratio, 20:1; column flow rate, $1 \mathrm{~mL} \cdot \mathrm{min}^{-1}$; injection volume, $1 \mu \mathrm{L}$. The column temperature was programmed to increase to $230{ }^{\circ} \mathrm{C}$ from the initial $180^{\circ} \mathrm{C}$ at the rate of $2{ }^{\circ} \mathrm{C} \cdot \mathrm{min}^{-1}$. The mass spectrometer was operated in electron impact ionization $(70 \mathrm{eV})$, full scan $(40-800 \mathrm{~m} / \mathrm{z})$ mode. The MS parameters were: scan speed, 1666; inter scan, 0.5s; source temperature, $250{ }^{\circ} \mathrm{C}$; interface temperature $285^{\circ} \mathrm{C}$. Compounds were identified by comparison of their retention indices and mass spectra with the mass spectra library. The relative content of each fatty acid was detected by the normalization method of peak areas.

\subsubsection{Determination of unsaponifiable matter of $F M B O$}

An amount of $1.0 \mathrm{~g}$ of FMBO was saponified with $10 \mathrm{~mL} 0.5 \mathrm{M} \mathrm{KOH}-\mathrm{C}_{2} \mathrm{H}_{5} \mathrm{OH}$ solution and the unsaponifiable matter was recovered and then diluted with $2 \mathrm{~mL}$ of hexane and injected into the GC-MS instrument. A Shimada GC-MS-QP2010 (Shimadzu Co., Kyoto, Japan) equipped with a capillary column (HP-5, $30.0 \mathrm{~m} \times 0.32 \mathrm{~mm}, 0.25 \mu \mathrm{m}$ film thickness, Agilent) was used. The GC parameters were: the carrier gas, high purity helium; injector temperature, $250{ }^{\circ} \mathrm{C}$; detector temperature, $320^{\circ} \mathrm{C}$; the split ratio, 20: 1 ; column flow rate, $1 \mathrm{~mL} \cdot \mathrm{min}^{-1}$; injection volume, $1 \mu \mathrm{L}$. The column temperature was programmed to increase to $285^{\circ} \mathrm{C}$ from the initial $200{ }^{\circ} \mathrm{C}$ at the rate of $5^{\circ} \mathrm{C} \cdot \mathrm{min}^{-1}$ and then maintained for $10 \mathrm{~min}$. The mass spectrometer was operated in electron impact 
ionization $(70 \mathrm{eV})$, full scan $(40-800 \mathrm{~m} / \mathrm{z})$ mode. The MS parameters were: scan speed, 1666; inter scan, $0.5 \mathrm{~s}$; source temperature, $250{ }^{\circ} \mathrm{C}$; interface temperature $285^{\circ} \mathrm{C}$. Compounds were identified by comparison of their retention indices and mass spectra with the mass spectra library. The relative content of sterols (or stanols) was determined by the normalization method of peak areas.

\subsubsection{Thermal analysis}

The thermal decomposition reaction kinetics of FMBO were investigated with STA 449 F3 Jupiter simultaneous thermal analyzer (Netzsch, Germany). The sample was analyzed at $10{ }^{\circ} \mathrm{C} \cdot \mathrm{min}^{-1}$ heating rates in the temperature range between $30^{\circ} \mathrm{C}$ and $1200{ }^{\circ} \mathrm{C}$. All thermal analysis runs were performed on 3-5 $\mathrm{mg}$ of sample under a $100 \mathrm{~cm}^{3} \cdot \mathrm{min}^{-1}$ stream of air. Three replicates were analyzed for each sample. Curves of simultaneous thermo gravimetric (TG) and differential thermal analysis (DTA) were performed using an origin spreadsheet suitably designed to approximate as closely as possible the experimental values to the predicted ones.

\section{RESULTS AND DISCUSSION}

\subsection{Fitting the model}

The statistical combination of the independent variables in coded and the natural values along with the predicted values are presented in Table 2 according to RSM design. The good agreement between the predicted and experimental values confirms the validity of the model.

Variance analyses of the factors studied for the response surface model are shown in Table 3. From the statistical analysis, the model with the $P$-value was highly significant at 0.0014 , which implied that the model was suitable for this experiment. Meanwhile, the "lack of fit" was insignificant, the $R$-squared was 0.9944, which indicated that the model was in good agreement with the experimental results.

The regression coefficients and the corresponding $P$-values are presented in Table 4 . From the $P$-values of each model term, it can be concluded that the separating time $\left(\mathrm{X}_{3}\right)$ and separating temperature $\left(\mathrm{X}_{2}\right)$ affected the extraction rate $(\mathrm{ER})$ with high significance, while the effect of separating pressure $\left(\mathrm{X}_{1}\right)$ on the ER was not significant. The interaction between temperature and time had a significant effect on the ER. However, the interaction between the other parameters was not significant. Some of the second-order terms $\left(\mathrm{X}_{2}{ }^{2}, \mathrm{X}_{3}{ }^{2}\right)$ highly significantly affected the ER, while the effect of the second-order term of $\mathrm{X}_{1}^{2}$ on the ER was not significant. The coefficients of independent variables determined for the second-order polynomial model for the ER is given below:
TABLE 2. Experimental scheme and results obtained from RSM

\begin{tabular}{|c|c|c|c|c|c|}
\hline \multirow[b]{2}{*}{ Runs } & \multicolumn{3}{|c|}{ Factors } & \multicolumn{2}{|c|}{ Response ER } \\
\hline & $\begin{array}{c}\text { Extracting } \\
\text { pressure } \\
\left(\mathbf{X}_{1}, \mathbf{M P a}\right) \\
\end{array}$ & $\begin{array}{c}\text { Temperature } \\
\left(\mathbf{X}_{2},{ }^{\circ} \mathbf{C}\right)\end{array}$ & $\begin{array}{c}\text { Time } \\
\left(\mathbf{X}_{3}, \mathbf{h}\right)\end{array}$ & $\begin{array}{l}\text { Exp. } \\
(\%)\end{array}$ & $\begin{array}{r}\text { Pred. } \\
(\%)\end{array}$ \\
\hline 1 & 30 & 45 & 2 & 7.75 & 7.70 \\
\hline 2 & 30 & 50 & 1.5 & 6.19 & 6.22 \\
\hline 3 & 30 & 45 & 2 & 7.75 & 7.70 \\
\hline 4 & 30 & 40 & 2.5 & 7.69 & 7.61 \\
\hline 5 & 30 & 45 & 2 & 7.73 & 7.7 \\
\hline 6 & 30 & 45 & 2 & 7.61 & 7.70 \\
\hline 7 & 30 & 50 & 2.5 & 7.82 & 7.89 \\
\hline 8 & 35 & 50 & 2 & 7.62 & 7.55 \\
\hline 9 & 25 & 45 & 1.5 & 5.82 & 5.82 \\
\hline 10 & 30 & 45 & 2 & 7.65 & 7.7 \\
\hline 11 & 30 & 40 & 1.5 & 5.46 & 5.39 \\
\hline 12 & 25 & 50 & 2 & 7.68 & 7.6 \\
\hline 13 & 35 & 45 & 1.5 & 5.7 & 5.69 \\
\hline 14 & 25 & 45 & 2.5 & 7.65 & 7.70 \\
\hline 15 & 35 & 40 & 2 & 6.91 & 6.99 \\
\hline 16 & 35 & 45 & 2.5 & 7.71 & 7.71 \\
\hline 17 & 25 & 40 & 2.0 & 6.93 & 7.0 \\
\hline
\end{tabular}

$\mathrm{Y}=7.70-0.017 \mathrm{X}_{1}+0.29 \mathrm{X}_{2}+0.96 \mathrm{X}_{3}-0.01 \mathrm{X}_{1} \mathrm{X}_{2}+0.045$ $\mathrm{X}_{1} \mathrm{X}_{3}-0.15 \mathrm{X}_{2} \mathrm{X}_{3}-0.24 \mathrm{X}_{1}^{2}-0.17 \mathrm{X}_{2}^{2}-0.74 \mathrm{X}_{3}^{2}$ where $\mathrm{Y}$ is the ER (\%), $\mathrm{X}_{1}$ is the extracting pressure, $\mathrm{X}_{2}$ is the extracting temperature, $\mathrm{X}_{3}$ is the extracting time.

\subsection{Optimization of reaction conditions by RSM}

Contour plots were employed to determine the effect of the interaction of parameters on the extraction rate (ER) of foxtail millet bran oil by SFE. From the shape of the contour plots in Fig.1, the significance of the mutual interactions between the independent variables can be estimated. Fig.1 (a) shows the interaction of the extraction pressure $\left(\mathrm{X}_{1}\right)$ and temperature $\left(\mathrm{X}_{2}\right)$ at the fixed extraction time at 2.0 hours. It was observed that the response value of the extraction rate increased with the rising of pressure when the temperature was lower than $47.5^{\circ} \mathrm{C}$; when the temperature was higher than $47.5{ }^{\circ} \mathrm{C}$, the response value decreased. This phenomenon was in consistence with other previous reports and is explained by the fact that the increased pressure would also lead to an increase in the density of supercritical $\mathrm{CO}_{2}$ (Jiang and Niu, 2011; Shao et al., 2008). Fig.1 (b) shows the interaction between the extraction pressure $\left(\mathrm{X}_{1}\right)$ and time $\left(\mathrm{X}_{3}\right)$ at the fixed temperature at $45^{\circ} \mathrm{C}$. The extraction rate was steadily increased by the extraction time but not significantly increased with the rise in extraction pressure. This is probably attributed 
Optimization and evaluation of foxtail millet (Setaria italica) bran oil by supercritical carbon dioxide extraction $\bullet 5$

TABLE 3. Analysis of variance of regression parameters for the response surface model

\begin{tabular}{lccccc}
\hline Source & Sum of squares & Degree of freedom & Mean Square & F-value & P-value $^{\mathbf{a}}$ \\
\hline Model & 11.02 & 9 & 1.22 & 139.14 & 0.0014 \\
Linear & 8.09 & 3 & 2.70 & 11.71 & 0.005 \\
Quadratic & 2.83 & 3 & 0.94 & 548.98 & 0.0011 \\
Lack of Fit & 0.045 & 3 & 0.015 & 3.65 & 0.1216 \\
Pure Error & 0.016 & 4 & 0.0042 & 0.0011 & \\
R-Squared & 0.9944 & & & & \\
\hline
\end{tabular}

${ }^{\mathrm{a}} \mathrm{p}<0.01$ highly significant; $0.01 \leq \mathrm{p}<0.05$ significant; $\mathrm{p} \geq 0.05$ not significant.

TABLE 4. Regression analysis of a full second-order polynomial model

\begin{tabular}{lcc}
\hline Factor $^{\mathbf{a}}$ & Coefficient Estimated & P-value $^{\mathbf{b}}$ \\
\hline $\mathrm{X}_{1}$ & -0.017 & 0.614 \\
$\mathrm{X}_{2}$ & 0.29 & $<0.0001$ \\
$\mathrm{X}_{3}$ & 0.96 & $<0.0001$ \\
$\mathrm{X}_{1} \times \mathrm{X}_{2}$ & -0.01 & 0.8372 \\
$\mathrm{X}_{1} \times \mathrm{X}_{3}$ & 0.045 & 0.3692 \\
$\mathrm{X}_{2} \times \mathrm{X}_{3}$ & -0.15 & 0.0151 \\
$\mathrm{X}_{1} \times \mathrm{X}_{1}$ & -0.24 & 0.0011 \\
$\mathrm{X}_{2} \times \mathrm{X}_{2}$ & -0.17 & 0.0071 \\
$\mathrm{X}_{3} \times \mathrm{X}_{3}$ & -0.74 & $<0.0001$ \\
\hline
\end{tabular}

${ }^{\mathrm{a}} \mathrm{X}_{1}$ :extraction pressure $(\mathrm{MPa}) ; \mathrm{X}_{2}$ : temperature $\left({ }^{\circ} \mathrm{C}\right) ; \mathrm{X}_{3}$ : time $(\mathrm{h})$. ${ }^{\mathrm{b}} \mathrm{p}<0.01$ highly significant; $0.01 \leq \mathrm{p}<0.05$ significant; $\mathrm{p} \geq 0.05$ not significant.

to the fact that the temperature in these cases was fixed at $45{ }^{\circ} \mathrm{C}$, and has decreased the density of supercritical $\mathrm{CO}_{2} \mathrm{~A}$ similar result can also be seen in a previous report (Shao et al., 2008). Fig.1 (c) shows the interaction between the extraction temperature $\left(\mathrm{X}_{2}\right)$ and time $\left(\mathrm{X}_{3}\right)$ at the fixed pressure at $30 \mathrm{MPa}$. Since the oil content of foxtail millet bran is lower, even less than $10 \%$, extraction time was also an essential factor affecting oil yield. It can be observed that the extraction rate continued slowly with the extraction time and did not significantly increase until the time was at about 2.1h. However, the subsequent time from $2.1 \mathrm{~h}$ to the end time of $2.5 \mathrm{~h}$ only produced a slight change in the oil yield.

From the results, the optimum conditions for foxtail millet bran oil extracted by SFE were predicted $\left(\mathrm{X}_{1}=30.03, \mathrm{X}_{2}=47.93, \mathrm{X}_{3}=2.3, \mathrm{Y}=8.07\right)$ by the regression model according to the limit criterion of maximum response $\mathrm{Y}$ and an appropriate range level for each parameter. An ER of 8.01\% was achieved under optimal conditions. Additional experiments in triplicate under these optimized extraction conditions were carried out. These triplicate experiments obtained an average RE of $7.97 \%$, which concurred with the model prediction and as a result, the model was considered to be accurate and reliable.
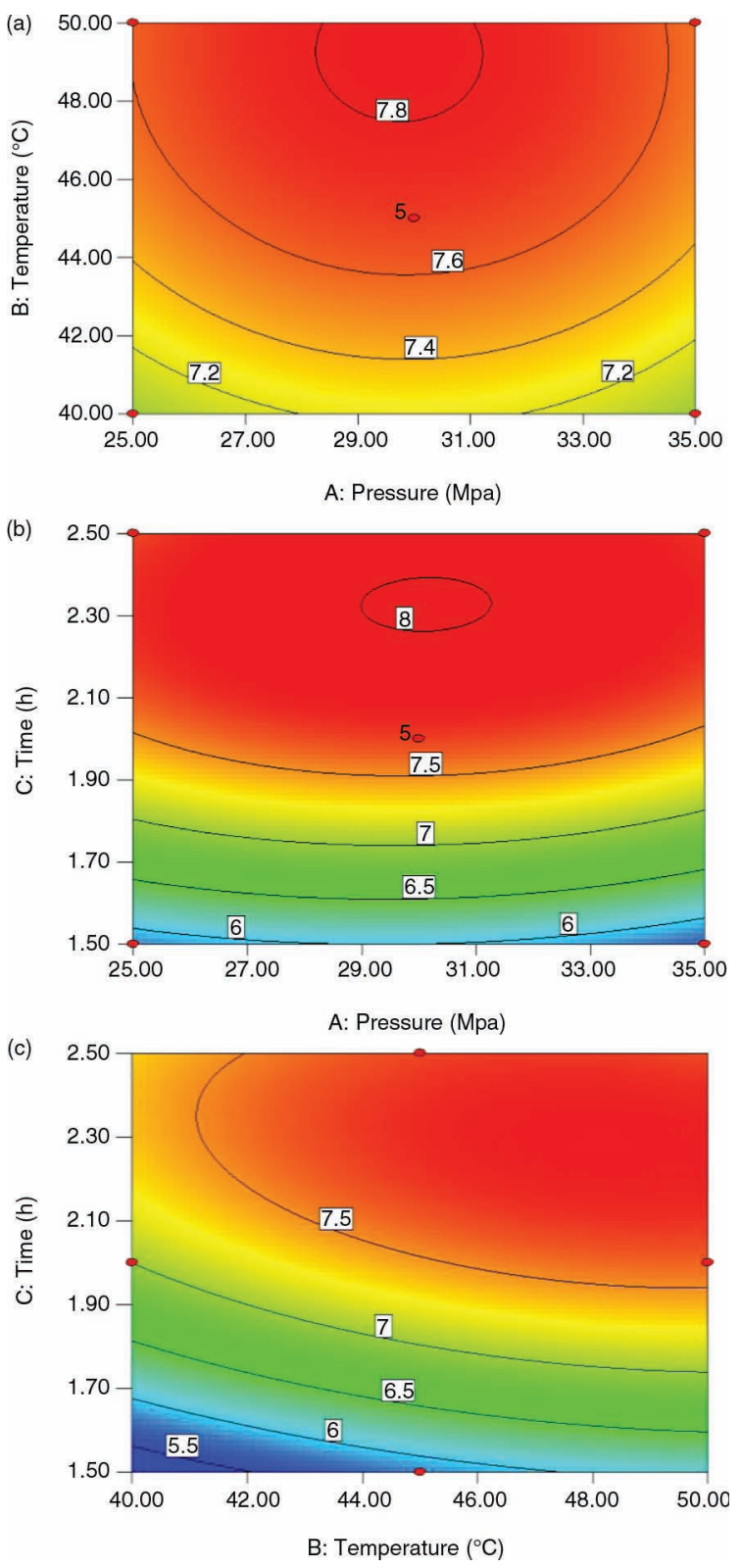

FIGURE 1. Contour plots between two parameters of extracting rate foxtail millet bran oil extracted by supercritical carbon dioxide; (a), pressure (Mpa) and temperature $\left({ }^{\circ} \mathrm{C}\right)$;

(b) pressure and time (h); (c) temperature and time. 


\subsection{Physicochemical properties of FMBO}

The physical and chemical properties of crude FMBO by SFE and SE methods are shown in Table 5. The specific gravity $\left(20^{\circ} \mathrm{C}\right)$, refractive index at $20^{\circ} \mathrm{C}$, and iodine value were slightly different between two samples. The saponification value $(189.58 \pm 0.41)$ of FMBO by SE showed a significant difference $(\mathrm{p}<0.05)$ from oil by SFE, while it was consistent with previous research in that the saponification value of millet oil was 192-197 mg KOH/g (Huo QG, 2006) and 186.29 0.51 (Liang et al., 2010), respectively. Another significant difference between the FMBO by SE and SFE is the phospholipid content. The phospholipid content by SFE was 0.188 $\mathrm{mg} / \mathrm{g}$ lower than $44.22 \mathrm{mg} / \mathrm{g}$ by SE, which indicated that SFE was superior to SE in phospholipid extraction and the subsequent refining step of degumming is not necessarily required for FMBO by SFE during the industrial process. In addition, the unsaponifiable matter content of FMBO by SFE $(3.58 \pm 0.23 \%)$ showed significant differences compared to the FMBO by SE $(2.89 \pm 0.21 \%)$. These results demonstrate that SFE can improve the FMBO quality, especially by decreasing the acid value, and peroxide value as well as color. The SFE method could better protect the bioactive components than the petroleum ether in terms of low pressure (30.03 MPa), short extraction time $(2.3 \mathrm{~h})$ and low temperature $\left(47.93^{\circ} \mathrm{C}\right)$ without any toxic solvent.

\subsection{Fatty acid composition of FMBO}

The major fatty acid composition of FMBO by different extraction methods is shown in Table 6. For both SFE and SE methods, eight main components of fatty acids including four saturated fatty acids (SAFA), two monounsaturated fatty acids (MUFA) and two polyunsaturated fatty acids (PUFA) were

TABLE 5. Physical and chemical properties of FMBO by $\mathrm{SE}$ and $\mathrm{SFE}^{\mathrm{a}}$

\begin{tabular}{lcc}
\hline Characteristic & SE & SFE \\
\hline Specific gravity & $0.9288 \pm 0.0002^{\mathrm{a}}$ & $0.9199 \pm 0.0002^{\mathrm{a}}$ \\
Refractive index $\left(20^{\circ} \mathrm{C}\right)$ & $1.4693 \pm 0.0001^{\mathrm{a}}$ & $1.4706 \pm 0.0001^{\mathrm{a}}$ \\
Color (Lovibond, $25.4 \mathrm{~mm})$ & $\mathrm{Y} 65, \mathrm{R} 12^{\mathrm{a}}$ & $\mathrm{Y} 35, \mathrm{R} 5.0^{\mathrm{b}}$ \\
Acid value $\left(\mathrm{mg} \mathrm{KOH} \cdot \mathrm{g}^{-1}\right)$ & $10.5 \pm 0.23^{\mathrm{a}}$ & $9.2 \pm 0.35^{\mathrm{b}}$ \\
Peroxide value $\left(\mathrm{mmol} \cdot \mathrm{kg}^{-1}\right)$ & $3.12 \pm 0.11^{\mathrm{a}}$ & $2.33 \pm 0.03^{\mathrm{b}}$ \\
Iodine value $\left(\mathrm{gI}_{2} \cdot 100 \mathrm{~g}^{-1}\right)$ & $101.23 \pm 1.43^{\mathrm{a}}$ & $103.16 \pm 1.90^{\mathrm{a}}$ \\
$\begin{array}{l}\text { Saponification value } \\
\left(\mathrm{mg} \mathrm{KOH} \cdot \mathrm{g}^{-1}\right)\end{array}$ & $189.58 \pm 0.41^{\mathrm{a}}$ & $176.89 \pm 0.33^{\mathrm{b}}$ \\
Unsaponifiable matter $(\%)$ & $2.89 \pm 0.21^{\mathrm{a}}$ & $3.58 \pm 0.23^{\mathrm{b}}$ \\
Phospholipid $(\mathrm{mg} \cdot \mathrm{g})$ & $44.22^{\mathrm{a}}$ & $0.188^{\mathrm{b}}$ \\
\hline
\end{tabular}

${ }^{a}$ Data are presented as means \pm standard deviation of triplicate determinations. Within each row, means not followed by the same letter are significantly different at $\mathrm{p} \leq 0.05$. identified. The amount of unsaturated fatty acids especially the linoleic acid C18:2, $(58.03 \% \pm 0.66$ by $\mathrm{SE}$ and $58.85 \% \pm 0.55$ by SFE, respectively) was high, which is consistent with our previous results (Pang M, 2014). As can be observed from Table 5, the fatty acid contents of FMBO obtained by SFE were similar to those by SE. Palmitic acid C16:0 and stearic acid C18:0 were the most predominant SAFA, oleic acid C18:1 was the principal MUFA and linoleic acid C18:2 as well as the linolenic acid C18:3 were the main PUFA (Table 5). Minor differences in some fatty acid contents were recorded when FMBO were extracted by SE versus SFE $(p<0.05)$, indicating that SE did not change the fatty acid composition. Both values of fatty acid composition of FMBO by SFE and SE are close to the previous report (Liang et al., 2010). FMBO was characterized by relatively high levels of polyunsaturated fatty acids (PUFA) and monounsaturated fatty acids (MUFA). Both of them have been shown to lower "bad" LDL cholesterol (low density lipoproteins) and retain "good" HDL cholesterol (high density lipoproteins) levels in the blood (Ramadan et al., 2010; Wang et al., 2011). The fatty acid profile and high amounts of UFA confirmed that FMBO can be considered to have a similar beneficial effect as other nutritious and healthy vegetable oils (Boskou, 2006; Innis and Dyer, 1997; Sahari et al., 2004).

\subsection{Analysis of steroid compounds for FMBO}

Plant sterols play a major role in pharmaceutical and nutrition since they are known to be cholesterol lowing agents as well as having anti-inflammatory, anti-oxidant, and anti-cancer functions (Bohn et al., 2007; Moreau et al., 2002). The levels of sterol in vegetable oils are recognized as the identification of oils, oil derivatives and used to determine the oil quality.

TABLE 6. Analysis of fatty acid composition for $\mathrm{FMBO}^{\mathrm{a}}$

\begin{tabular}{lcc}
\hline Fatty acids $^{\mathrm{a}}$ & SE (\%) & SFE (\%) \\
\hline Palmitic acid (C16:0) & $10.83 \pm 0.10^{\mathrm{a}}$ & $10.23 \pm 0.12^{\mathrm{b}}$ \\
Stearic acid (C18:0) & $3.96 \pm 0.05^{\mathrm{a}}$ & $3.73 \pm 0.03^{\mathrm{b}}$ \\
Oleic acid (C18:1) & $19.43 \pm 0.21^{\mathrm{a}}$ & $19.65 \pm 0.16^{\mathrm{a}}$ \\
Linoleic acid (C18:2) & $58.03 \pm 0.66^{\mathrm{a}}$ & $58.85 \pm 0.55^{\mathrm{a}}$ \\
Linolenic acid (C18:3) & $3.90 \pm 0.08^{\mathrm{a}}$ & $3.96 \pm 0.04^{\mathrm{a}}$ \\
Arachidic acid (C20:0) & $1.69 \pm 0.02^{\mathrm{a}}$ & $1.52 \pm 0.01^{\mathrm{b}}$ \\
Behenic acid (C20:1) & $1.38 \pm 0.01^{\mathrm{a}}$ & $1.30 \pm 0.01^{\mathrm{b}}$ \\
Docosenoic acid (C22:0) & $0.78 \pm 0.01^{\mathrm{a}}$ & $0.76 \pm 0.01^{\mathrm{a}}$ \\
Saturated fatty acid (SAFA) & 17.26 & 16.24 \\
Unsaturated fatty acid (UFA) & 82.74 & 83.76 \\
\hline
\end{tabular}

${ }^{a}$ Results are expressed as \% over the total content (i.e. relative content); data are presented as means \pm standard deviation of triplicate determinations. Within each row, means not followed by the same letter are significantly different at $p \leq 0.05$. SE, Solvent extraction by petroleum ether; SFE, supercritical carbon dioxide extraction. 
TABLE 7. Analysis of steroid compounds for $\mathrm{FMBO}$ by SE and $\mathrm{SFE}^{\mathrm{a}}$

\begin{tabular}{|c|c|c|}
\hline${ }^{\text {a }}$ Steroids & SE(\%) & SFE(\%) \\
\hline Campesterol & $15.22 \pm 0.28^{\mathrm{a}}$ & $15.91 \pm 0.19^{\mathrm{a}}$ \\
\hline Ergostanol & $2.77 \pm 0.04^{\mathrm{a}}$ & $2.97 \pm 0.03^{\mathrm{b}}$ \\
\hline Stigmasterol & $5.85 \pm 0.07^{\mathrm{a}}$ & $5.58 \pm 0.05^{\mathrm{b}}$ \\
\hline$\beta$-Sitosterol & $56.58 \pm 0.77^{\mathrm{a}}$ & $56.26 \pm 0.82^{\mathrm{a}}$ \\
\hline Stigmastanol & $15.33 \pm 0.11^{\mathrm{a}}$ & $15.12 \pm 0.24^{\mathrm{a}}$ \\
\hline Fucosterol & $4.25 \pm 0.02^{\mathrm{a}}$ & $4.16 \pm 0.05^{\mathrm{b}}$ \\
\hline
\end{tabular}

${ }^{a}$ Results are expressed as $\%$ over the total content (i.e. relative content); data are presented as means \pm standard deviation of triplicate determinations. Within each row, means not followed by the same letter are significantly different at $p \leq 0.05$. SE, Solvent extraction by petroleum ether; SFE, supercritical carbon dioxide extraction.

In this study, the sterol levels of the oils by both SFE and SE are evaluated and the value obtained for sterol composition are listed in Table 7. The total sterols of FMBO amounted to1.55\% by SFE and $1.09 \%$ by SE, which indicates that FMBO by SFE can contain 1.422 times higher sterols than FMBO by SE. This result is in agreement with other previous research where the SFE were used to extract oils from plant seeds (Jiang and Niu, 2011; Shao et al., 2008). $\beta$-sitosterol was found to be the major sterol $(56.26 \%$ of the total sterols by SFE), followed by campesterol and stigmastanol, at about $15.91 \%$ and $15.1 \%$, respectively. Other chemical types of phytosterols (or phytostanols) were also identified such as ergostanol, stigmasterol, and fucosterol in both the oil extracted by SFE and SE. The composition of these sterols make FMBO a potentially functional oil to perform healthy biological activities.

\subsection{Thermal analysis}

Vegetable oils are mostly used for cooking foods, so it is important to understand their thermo-physical properties during the heating processes. Thermal

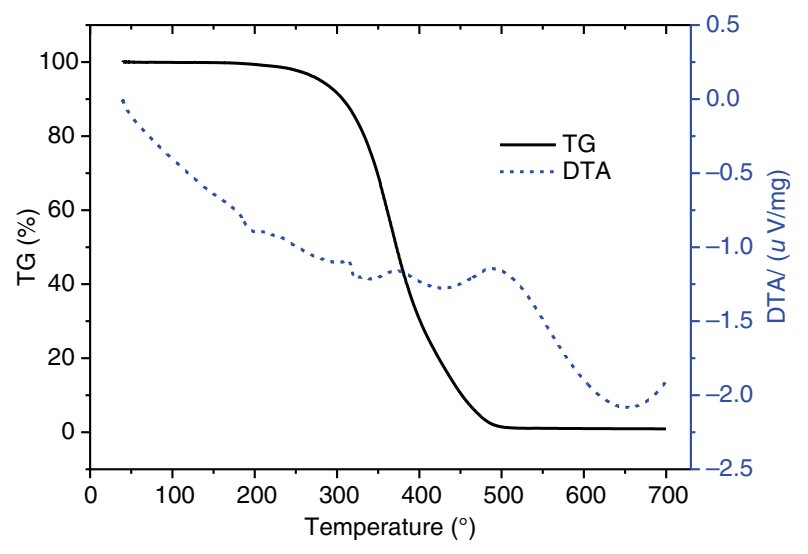

FIGURE 2. TG-DTA curves of FMBO gravimetric (TG) and differential thermal analysis (DTA) analysis can show the thermal behavior of oils for their identification since thermal properties are related to major (triacylglycerols, total fatty acids) and minor (diacylglycerols, lipid oxidation products) chemical components (Chiavaro et al., 2008). Fig. 2 shows the TG-DTA curves of FMBO in an open air atmosphere. The essential weight loss occurred mainly in the $300-500{ }^{\circ} \mathrm{C}$ range. At $512.2^{\circ} \mathrm{C}$, the weight was lost completely. In the DTA curve, there are decalescence peaks near the decomposition temperature which correspond with the weight loss stages.

\section{CONCLUSIONS}

A second-order polynomial model in our experiment was determined to be sufficient to describe and predict the response variable of the oil yield for the SFE of foxtail millet bran. We also investigated the mechanism involved in that process, and analyzed the physicochemical properties, fatty acid composition and steroids. Compared with the solvent extraction method using petroleum ether, FBMO obtained from SFE showed much lower phospholipid $(0.188 \mathrm{mg} / \mathrm{g})$ content and a preferable color, while it also contained more important bioactive components in that the content of total sterols reached $1.55 \%$. The results from the thermal gravimetric analysis showed one major regime of weight loss over a temperature range of $300-500{ }^{\circ} \mathrm{C}$. With the increasing demand for natural, nutritive foxtail millet bran oil, which is rich in unsaturated fatty acids and other lipid accompaniments as well as the physicochemical properties which are close to values of other edible oils, making it a natural source of food fortification is promising as it has been determined to have many potentially healthy biological properties.

\section{ACKNOWLEDGMENTS}

This work is supported by the National Natural Science Foundation of China (No. 31371729).

\section{REFERENCES}

Amadou I, Le GW, Amza T, Sun J, Shi YH. 2013. Purification and characterization of foxtail millet-derived peptides with antioxidant and antimicrobial activities. Food Res. Int. 51, 422-428. http://dx.doi.org/10.1016/j.foodres.2012.12.045.

Bangoura ML, Nsor-Atindana J, Ming ZH. 2013. Solvent Optimization Extraction of Antioxidants from Foxtail millet Species' Insoluble Fibers and their Free Radical Scavenging Properties. Food Chem. 141, 736-744. http://dx.doi.org/ 10.1016/j.foodchem.2013.03.029.

Bohn T, Tian Q, Chitchumroonchokchai C, Failla ML, Schwartz SJ, Cotter R, Waksman JA. 2007. Supplementation of test meals with fat-free phytosterol products can reduce cholesterol micellarization during simulated digestion and cholesterol accumulation by Caco-2 cells. J. Agric. Food Chem. 55, 267-272. http://dx.doi.org/10.1021/jf0618291. 
Boskou D, 2006. Olive oil: chemistry and technology. AOCS press. http://dx.doi.org/10.1201/9781439832028.

Chen CR, Wang CH, Wang LY, Hong ZH, Chen SH, Ho WJ, Chang CMJ. 2008. Supercritical carbon dioxide extraction and deacidification of rice bran oil. J. Supercrit. Fluids 45, 322-331. http://dx.doi.org/10.1016/j.supflu.2008. 01.006 .

Chen C.-W, Cheng H.-H. 2006. A rice bran oil diet increases LDL-receptor and HMG-CoA reductase mRNA expressions and insulin sensitivity in rats with streptozotocin/ nicotinamide-induced type 2 diabetes. J. Nutrit. 136, $1472-1476$

Chen J, Ren X, Zhang Q, Diao X, Shen Q. 2013. Determination of protein, total carbohydrates and crude fat contents of foxtail millet using effective wavelengths in NIR spectroscopy. J. Cereal Sci. 58, 241-247. http://dx.doi.org/10.1016/j. jes.2013.07.002

Chiavaro E, Rodriguez-Estrada MT, Barnaba C, Vittadini E, Cerretani L, Bendini A. 2008. Differential scanning calorimetry: A potential tool for discrimination of olive oil commercial categories. Anal. Chim. Acta, 625, 215-226. http://dx.doi.org/10.1016/j.aca.2008.07.031.

Firestone D. 1998. Official methods and recommended practices of the AOCS. American Oil Chemists' Society.

Ge Y, Yan H, Hui B, Ni Y, Wang S, Cai T. 2002. Extraction of natural vitamin $\mathrm{E}$ from wheat germ by supercritical carbon dioxide. J. Agric. Food Chem. 50, 685-689. http://dx.doi. org/10.1021/jf010615v.

Huo QG, Bi YL, Zhu XP, Wang MM. 2006. Study on components of millet oil. J. China Oil, 31, 63-64.

Innis SM, Dyer R. 1997. Dietary triacylglycerols with palmitic acid (16: 0 ) in the 2-position increase 16: 0 in the 2-position of plasma and chylomicron triacylglycerols, but reduce phospholipid arachidonic and docosahexaenoic acids, and alter cholesteryl ester metabolism in formula-fed piglets. J. Nutrit. 127, 1311-1319.

Jiang ST, Niu L. 2011. Optimization and evaluation of wheat germ oil extracted by supercritical $\mathrm{CO}_{2}$. Grasas Aceites 62, 181-189.

Kim HJ, Lee SB, Park KA, Hong IK. 1999. Characterization of extraction and separation of rice bran oil rich in EFA using SFE process. Separat. Purificat. Technol. 15, 1-8. http:// dx.doi.org/10.1016/S1383-5866(98)00048-3.

Liang S, Yang G, Ma Y. 2010. Chemical Characteristics and Fatty Acid Profile of Foxtail Millet Bran Oil. J. Am. Oil Chem. Soc. 87, 63-67. http://dx.doi.org/10.1007/s11746009-1475-3.

Pang M, He SJ, Wang L, Cao XM, Cao LL, Jiang ST. 2014. Physicochemical properties, antioxidant activities and protective effect against acute ethanol-induced hepatic injury in mice of foxtail millet (Setaria italica) bran oil. Food Funct. 5, 1763-1770. http://dx.doi.org/10.1039/ C4FO00106K

Martinez-Gonzalez MA, Estruch R. 2004. Mediterranean diet, antioxidants and cancer: the need for randomized trials. European J. Cancer Prevent. 13, 327-335. http://dx.doi. org/10.1097/01.cej.0000137512.71845.bf.

Moreau RA, Whitaker BD, Hicks KB. 2002. Phytosterols, phytostanols, and their conjugates in foods: structural diversity, quantitative analysis, and health-promoting uses. Progress Lipid Res. 41, 457-500. http://dx.doi.org/10.1016/ S0163-7827(02)00006-1.

Panagiotakos DB, Pitsavos C, Stefanadis C. 2006. Dietary patterns: a Mediterranean diet score and its relation to clinical and biological markers of cardiovascular disease risk. Nutrit. Metabol. Cardiovascular Diseases 16, 559-568. http://dx.doi.org/10.1016/j.numecd.2005.08.006.

Ramadan MF, Kinni S, Seshagiri M, Mrsel JT. 2010. Fat-soluble bioactives, fatty acid profile and radical scavenging activity of Semecarpus anacardium seed oil. J. Am. Oil Chem. Soc. 87, 885-894. http://dx.doi.org/10.1007/s11746-010-1567-0.

Sahari MA, Ataii D, Hamedi M. 2004. Characteristics of tea seed oil in comparison with sunflower and olive oils and its effect as a natural antioxidant. J. Am. Oil Chem. Soc. 81, 585-588. http://dx.doi.org/10.1007/s11746-006-0945-0.

Shao P, Sun P, Ying Y. 2008. Response surface optimization of wheat germ oil yield by supercritical carbon dioxide extraction. Food Bioprod. Process. 86, 227-231. http://dx.doi. org/10.1016/j.fbp.2007.04.001.

Wang Y, Sun D, Chen H, Qian L, Xu P. 2011. Fatty acid composition and antioxidant activity of tea (Camellia sinensis L.) seed oil extracted by optimized supercritical carbon dioxide. Int. J. Mol. Sci. 12, 7708-7719. http://dx.doi.org/10.3390/ ijms 12117708

Wei ZJ, Liao AM, Zhang HX, Liu J, Jiang ST. 2009. Optimization of supercritical carbon dioxide extraction of silkworm pupal oil applying the response surface methodology. Biores. Technol. 100, 4214 4219. http://dx.doi. org/10.1016/j.biortech.2009.04.010.

Zacchi P, Daghero J, Jaeger P, Eggers R. 2006. Extraction/ fractionation and deacidification of wheat germ oil using supercritical carbon dioxide. Brazilian J. Chem. Eng. 23, 105-110. http://dx.doi.org/10.1590/S0104-66322006000100011.

Zohary D, Hopf M, Weiss E. 2012. Domestication of Plants in the Old World: The origin and spread of domesticated plants in Southwest Asia, Europe, and the Mediterranean Basin. Oxford University Press. http://dx.doi.org/10.1093/ acprof:osobl/9780199549061.001.0001 